\title{
PVT Cell Performance Characteristics and Efficiency with Phase Change Material
}

\author{
D. Kameswara Rao, K. Sudhakar Reddy, V. V. Subba Rao
}

\begin{abstract}
The PV panel temperature increase causes the drop in output power and electrical efficiency. The power generation of PV module is highly influenced by the temperature and so cooling is required to increase the $P V$ panel electrical efficiency. $P V$ panel electrical efficiency can be increased by keeping the low operating temperature as low as possible, preferably at temperature of $25^{0} \mathrm{C}$ and irradiation $1000 \mathrm{w} / \mathrm{m}^{2}$. The temperature regulation with efficient control methods of $P V$ modules can increase its efficiency by a significant level. The PVT-PCM systems elevated about 28 to $42 \%$ more heat storage capacity than that of for a longer period and around 8 to $12 \%$ escalation in output. The application of phase change materials (PCM) can be a better solution for this purpose, because phase change material (PCM) has large energy storage capacity and nearly constant charging / discharging temperature during phase change transitions. It can be used to regulate the PV cell temperature and store the thermal energy for solar heating systems photoelectric conversion efficiency of a PV system was improved by using different PCM. In this study we are trying to increase the efficiency by using different fin layout of the heat sink and comparing the experimental data for optimal fin design to effectively disperse heat through PCM material. The PVT panel surface back side was attached with the aluminum container with different (Geometric, Spherical \& fins) configurations with PCM and with out PCM of single/different materials. Present study carried on aluminum $\mathrm{H}-30$ box holding PCM material with fins and covering plate to which the photo voltaic cell attached then a different sensors to collect temperature data and irradiation levels at different regions. The design parameters was changed with fins and geometrical shape and found the derating factor. The derating factor was found with fins and with out pins along with PCM and with out PCM. Both experimental and theoretical values were compared ,the study revealed that the derating factor value was 13.2 without PCM the and 4.40 with PCM with out fins. The results revealed that relation between experimental measurement values and theoretical values. The study confirmed PCM with better fin design will increase the effective surface area can increase the cooling of PVT panel, results the escalation in electrical out put.

Keywords: PCM, PVT, Aluminum 6082, solar power, thermal storage
\end{abstract}

\section{INTRODUCTION}

The renewable energy share in the sustainable development cannot be neglected.

Revised Manuscript Received on June 15, 2020.

D.Kameswara Rao*, Assistant Professor, Department of Mechanical Engineering (Mechatronics) Mahatma Gandhi Institute of Technology, Hyderabad, Telanagan,India

K. Sudhakar Reddy, Professor, Department of Mechanical Engineering (Mechatronics) Mahatma Gandhi Institute of Technology, Hyderabad, Telanagan,India

V.V.SubbaRao, Professor, University College of Engineering, JNT University, Kakinada, Andhra Pradesh, India

(c) The Authors. Published by Blue Eyes Intelligence Engineering and Sciences Publication (BEIESP). This is an open access article under the CC BY-NC-ND license (http://creativecommons.org/licenses/by-nc-nd/4.0/)
Increasing the global concerns in order to compensate the lack of fossil fuels resources for electricity production increased the electricity production technologies particularly in Solar PV system. But the solar energy suffers of low energy density and less sustainability. Photovoltaic thermal (PVT) system is well engineered solar co-generation system integrate the photovoltaic module and solar thermal components to form a hybrid to get both electricity and heat as finish product. Besides the efficiency solar (PVT) energy, claims less greenhouse gas emissions from burning of the fossil fuels. The photovoltaic's efficiency decreased due to increase in panel cell temperature. So it is necessary to decrease the panel temperature by cooling techniques to enhance the overall efficiency of the PVT system. Photovoltaic/Thermal (PV/T) system enhances the Electrical and Thermal benefits, thereby increasing the overall efficiency. To lower the PVT panel operating temperature, one can either improve the free cooling on the back of solar panel by natural convection/ Forced convection or try to absorb the excess heat by modifying the solar panel architecture. Absorption of excess heat was efficiently done by PCM on the back of solar panels. PVT-PCM system increment in efficiency makes more competitive with conventional energy system PCM are material that changes their phase during temperature change. When solar panel temperature rises, the excess heat will be absorbed by PCM until it is completely melted. When the panels temperature decreases, the solidification of the PCM should provides additional heat for the operating liquid in solar thermal panels. Researcher studies shows that PCM can be successfully integrated with all the solar thermal/ PVT devices to enhance electrical and thermal energy, that reduce the requirement of conventional fuels like oil, coal etc and also helps in reducing greenhouse gasses. Kenisarin and Mahkamov, assessed the thermal characteristics of a range of PCMs with the new methods for improving heat transfer and design of heat storage facilities to be employed as an integrated element of several solar devices like solar passive and active heating systems (Greenhouses, solar cooker). Browne et al. [1] studied the application of PCM in PV systems raised the point of commercialization of such hybridizations and analyzed the economic viability of PVPCM systems to decrease payback period. He also reviewed the application of PCM in PV systems raised the point of commercialization, hybridizations and analyzed the economic viability of PV-PCM systems . Du et al. [2] made a critical review on the thermal management systems for crystalline silicon based photovoltaic panels in which PVPCM systems are highlighted as a prospective method.

\section{FACTORS INFLUENCE THE PERFORMANCE OF PHOTOVOLTAIC'S :}

Published By:

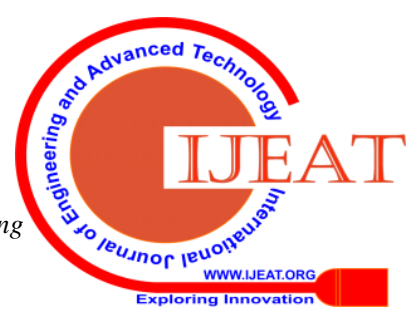


PV panel suffers reduction in electrical efficiency due to increase in cell temperature which causes to decrease in power output. Solar cells temperature depends on various parameters like conduction, convection and radiation effects due to degree of orientation along with insolation received, wind speed on the PV panel, direction of wind speed, ambient temperature, solar cell materials, mass flow rate, packing factor and glazing factor. Mass flow rate is important parameter in designing a PV/T Hybrid system. The convection heat transfer coefficient is sensitive to mass flow rate variations, the higher the convection heat transfer coefficient results the higher heat transfer rate from the panel to absorber and the lower the exit temperature along with higher thermal efficiency as well as electrical efficiency. Generally mass flow rate will depends upon the Fluid material (gas or liquid), velocity magnitude, and the geometry of PV/T thermal system. In general, more heat can be removed at high mass flow rate, results in poorer absorber plate temperature. However, if flow residence time in the channel is too short due to increase of velocity, the absorber plate temperature may not be reduced linearly as much as expected. From the researchers studies it was understood that an optimum mass flow rate, which allows a $\mathrm{PV} / \mathrm{T}$ system to produce the maximum thermal and overall efficiencies. Packing factor means the fraction of absorber solar plate area enclosed by the solar cells. In specific applications, Vats et al. [3] established the packing factor effects on energy and performed exergy analysis of a PV/ T system with air duct flow. The increase of packing factor doesn't permanently increase the electrical efficiency or energy gain. Packing factor is elevated beyond the level thermal exit temperature will get higher due to absorbing more amount of thermal energy so it will increase the PV cell temperature, which results reduction in electrical efficiency. On the other hand decreasing the packing factor too much will decrease the electrical efficiency because the radiation absorber area is less.

\section{PVT PANEL COOLING METHODS:}

\section{A. Conventional Method of Cooling:}

To make sure solar panels can work during optimal temperatures, cooling systems can usually be applied. Air and Liquid is generally the most common forms of cooling panels, but the real distribution between the cooling methods are unknown. Furthermore, some of these systems use the heat generated from the solar panels as heat for housing or other applications, making the applied system a so-called PVT system. Air-cooling is usually divided Passive (wind and air circulation cools down the panel) and Active (moving parts) Cooling systems. Natural air cooling technique uses ambient air flow to reduce PV panel temperature by natural ventilation. Heat transfer can further be enhanced by increasing the heat transfer area using fins and extended surface designs. The drawbacks of this system are the fluctuations in PV cell temperature and very high panel temperatures during peak insolation . Researchers studied a ventilated PV façade and found that PV panel peak temperature was $54.5^{\circ} \mathrm{C}$ in comparison of panel with out ventilation $75.7{ }^{\circ} \mathrm{C}$. Forces circulation cooling, heat removal is based on forced airflow at the front and back of the PV panels. However it consumes considerable amount of fan power. Researchers stated that active ventilation with forced convection will increase electrical output by 7 to
8\%. Passive water cooling systems cools the panel without the use of pumps. It is found effective for PV cooling provided good thermal contact between the PV and the collector system is ensured. Further the excess heat stored in water should be continuously removed or utilized elsewhere. Cooling performance is improved in active water cooling systems as the water flow velocity is increased. However, increase in volumetric flow per unit time means increase in power consumption .It was found that water flow can increase the electricity generation efficiency of the panel by 8-9\% along with reducing the reflection losses.

\section{B. Thermo electric cooling :}

Thermoelectricity is not a new technology in itself but have in recent years gained attention for use in new applications. One of these applications would be solar panels as thermoelectric components can either be used as heaters, coolers, or even generators without moving parts. Thermoelectric generators use temperature difference between two mediums to generate electricity while heaters and coolers use electricity to either heat or cool respectively. For solar panels it would be interesting to further use the waste heat to produce electricity. One problem persists with them though: their efficiency is low and thus too expensive for use in some areas.

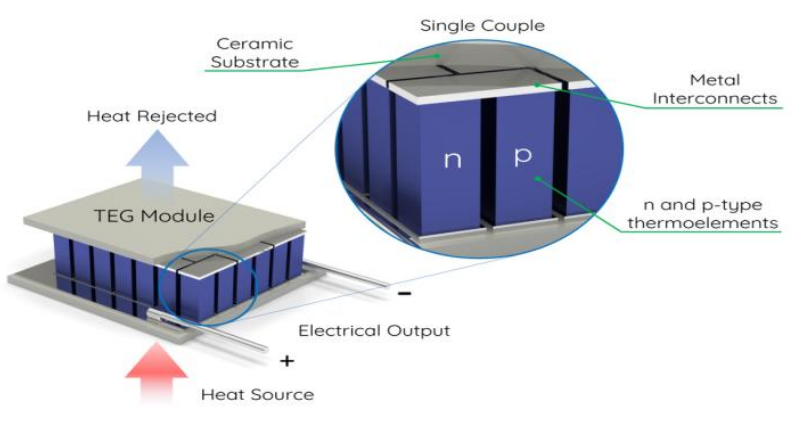

Fig 2.0 Thermoelectric cooling system

\section{Cooling Using PCMs}

Phase change material (PCM) firstly absorbs sensible heat, reaches to melting temperature; it absorbs latent heat and goes on melting. PCM is kept behind the PV Panel to absorb the heat and it maintains constant PV panel temperature during phase change but only stores heat energy. The high latent heat capacity of PCM is utilized to maintain the PV panel at a fairly constant temperature. The heat stored can later be used for space heating, water heating and other purposes; however the initial investment with these systems is quite high. PCM has an added advantage of its ability to delay the temperature rise of panel without any electricity consumption and the heat stored can be reused which further enhances the system overall efficiency. Jay et al. studied the PV-PCM system through computer investigations in which PCM was encapsulated into honeycomb structure to enhance heat conduction and it was reported that there was increment of $15-23 \%$ in electrical efficiency as compared to standalone photovoltaic panel.
Published By:

Blue Eyes Intelligence Engineering \& Sciences Publication (C) Copyright: All rights reserved. 


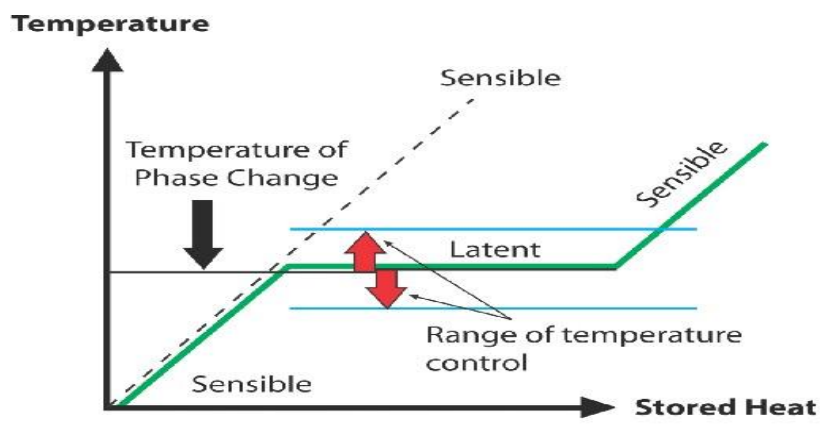

Fig 2.1 Temperature vs Stored heat in PCM

It is essential for the PCM to have a melting point above the ambient temperature in which it works: having a melting point lower than the ambient temperature would cause the PCM to melt before the panel is even heated, thus making it useless. In relation to this, most PCMs have a maximum working temperature that cannot be exceeded because it does then the materials chemical properties may change to unpredictable values. To make sure that the material has the desired properties, many materials requires to be initialized.

\section{SELECTION OF PHASE CHANGE MATERIALS}

When choosing the PCM, several factors were taken into account. The most important factor is that the material is non-toxic to handle and that it has a high melting enthalpy. Another important factor is that the material has a low expansion factor. This simplifies the calculations on the storage containers for the PCM. The materials lifespan, maximum working temperature and density were also studied. The lifespan is important because the PCM should not stop working (change properties) before the end of the PV-panels lifetime. The maximum working temperature is interesting to keep an eye on because if the material goes over this line, then it will stop working until the temperature drops again. The density was less important to look at, but good to include so that the materials weight could be kept an eye on. The melting temperature is also important, but most of the companies had several different materials where the melting points differed while most other properties where the same or similar. This made this property less important to study. The goal of this project was to make a practical test of the PCM. As such the materials cost and shipping time had a big impact when deciding which material to use.

i)

\section{PCM Characteristics and classification}

Organic PCMs (Hydrocarbons, primarily paraffin's $(\mathrm{CnH} 2 \mathrm{n}+2)$ and lipids) are having so many advantages like chemical stability, freezing with out much super cooling , Self nucleating property, compatibility safe and non reactive. Organic PCM main disadvantage is low thermal conductivity, low volumetric latent heat storage and flammability. Inorganic (Salt hydrates (MxNyH2O) ) Having advantage of low cost and availability, high heat of fusion, non flammable and Volumetric latent heat storage capacity was very high. The main disadvantages are Disposal and corrosive with other materials.

\section{A. Solid-solid PCM materials}

A specialized group of PCMs that undergo a solid/solid phase transition with the associated absorption and release of large amounts of heat. In this project for sustainable use of resources we are increasing the efficiency of a photo voltaic cell by using PCM material to maintain the temperature of photo voltaic cell at optimal temperature between 25 to $40{ }^{\circ} \mathrm{C}$ by designing a thermal sink with different fin designs with different layouts thereby finding optimal design for heat transfer from photo voltaic cell to the PCM material

\section{PHOTOVOLTAIC CELI}

\section{A. Characteristics of a Solar Cell}

A solar cell is mainly characterized by two curves known as current-voltage characteristic and power-voltage characteristic. The first one informs the variations of the output current with respect to the output voltage. When light is shown on the solar cell, electrons can be released through Photovoltaic effect and will become mobile, implying the existence of an electric current. It is also important to observe that both the output current and voltage of the solar cell change with respect to the variations of the load. The maximum current produced by a solar panel can be obtained when the panel or module is shorted meaning the positive and negative probes are connected together. The resulting current is denoted Short Circuit Current and is abbreviated as ISC. It is however important to note that when the cell is shorted the voltage across its terminal is zero. On the other hand, the maximum voltage is obtained when the circuit is opened meaning there is no close circuit between the positive and negative probes. The resulting voltage is called Open Circuit Voltage (Voc). It must also be noted that the resistance value of an open circuit is infinity and the current is zero since there is no close path for current to flow through. At some point, the internal resistance of the solar cell will be equal to the resistance of the load. The maximum power will then be generated by the solar cell, and this is called the Maximum Power Point(MPP).

\section{B. Types of Solar Cells}

There are two main types of solar cells: Crystalline Cells and Thin layer (film) Cells. Most PV modules available on market are based on Crystalline Silicon. The process of manufacturing crystalline silicon includes growing ingots of silicon, slicing the ingots into wafers to make solar cells, electrically interconnecting the cells, and encapsulating the strings of cells to form a module. Crystalline cells are further divided into two categories: monocrystalline (single) and polycrystalline (multi-crystalline)
Published By:

Blue Eyes Intelligence Engineering \& Sciences Publication

(C) Copyright: All rights reserved. 


\section{PVT Cell Performance Characteristics and Efficiency with Phase Change Material}

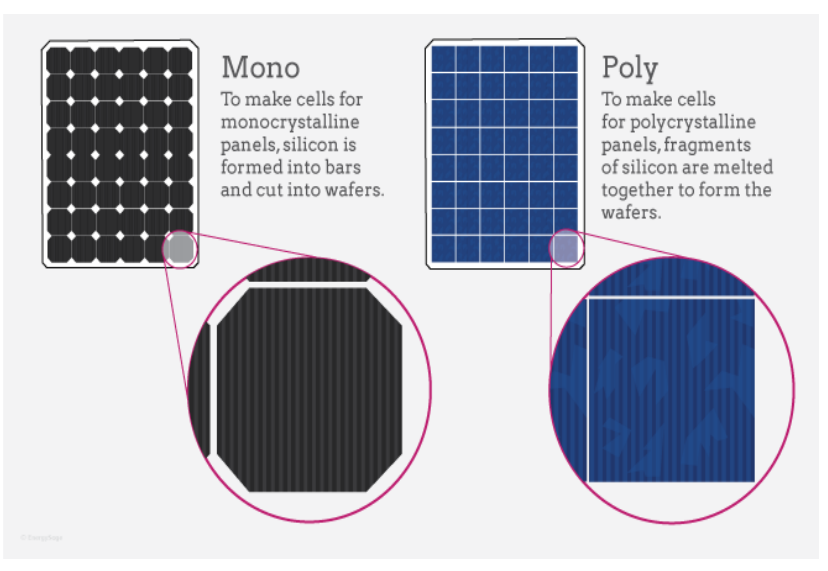

Fig 3.0 Types of Solar Cells

\section{Monocrystalline Solar Cells}

The most effective and at the same time most expensive solar cell are Monocrystalline silicon (mono-Si) solar cells. Solar panels made of mono-Si cells exhibit a unique pattern of small white diamonds. Recently, some laboratories developed monocrystalline cells of high efficiencies, almost 24\%. In the laboratory conditions, adverse factors such as reflection and grid coverage have been considerably reduced. It must however be emphasized that good production conditions obtained in laboratory cannot be afforded for mass production; in reality the efficiencies encountered on market for mass production are always lower than that of laboratories. They vary in the range of $15 \%$ to $18 \%$. While monocrystalline cells typically have a higher efficiency than other types of cells, they are more difficult to make than other types of solar cells.

\section{Polycrystalline or Multicrystalline Solar Cells}

Crystalline silicon (c-Si) cells are the most encountered solar cells available on market. They are also known as solar grade silicon. Multiple types of these crystalline silicon cells exist according the crystalline and crystal size in the wafer. Their operation principle derives from the principle of PN junction. A potential disadvantage of polycrystalline cells is that the boundaries among the thin crystals tend to attract electrons. These boundaries either provide a path for electrical short across the cell or act as barriers, which slow carrier motion. A polycrystalline cell is illustrated below in Figure 28. Manufacturers of polycrystalline cells need to ensure that the crystals are large enough for photo-generated electrons to be collected by the "PN" junction and the metal contacts of the cell/module before they reach a crystal boundary. Efficiencies of $13 \%$ to $16 \%$ are normal, although research cells have reached $21 \%$. Polycrystalline modules are very common, and are used in a wide variety of installations, including both domestic and commercial installations.

\section{E. Thin Film Cells}

Thin film cells are produced as a result of depositing very thin layers of photosensitive materials on other inexpensive materials like stainless steel, plastic lead or glass. The first series of thin film cells produced on market is the Amorphous Silicon (a-Si). The efficiency of the Amorphous Silicon (a-Si) cell can be increased by combining the thin amorphous with microcrystalline silicon cells. Other existing thin film technologies include cadmium telluride (CdTe) and copper, indium, gallium, diselenide (CIGS). The major advantages of thin films solar cells are related to the fact that they relatively consume a lower rate of raw materials; the production process is highly automated and efficient; they can easily be integrated to building and produce a beautiful appearance; they keep good operation performance at high temperature; and exhibit a reduced sensitivity to overheating .

\section{F. Selection of Solar Panel}

A monocrystalline solar panel is a solar panel comprising monocrystalline solar cells. These cells are made from a cylindrical silicon ingot grown from a single crystal of silicon of high purity in the same way as a semiconductor. The cylindrical ingot is sliced into wafers forming cells. To maximize the utility of the cells, the circular wafers are wire cut to an octagonal shaped wafer. These cells have a unique look because of the octagonal shape. These cells also have a uniform color.

\section{G. vii) Characteristics of Monocrystalline Solar PV Cell}

Monocrystalline solar cells are among the three types of materials that exhibit Photovoltaic properties. The other two are polycrystalline solar cells and amorphous or thin film solar panels. These panels have features measured superior than the other panels. They have the panel with pyramid pattern offers large surface area to collect more energy from sun rays and having cells are coated with silicon nitride to reduce reflection. The produced electricity is collected through metal conductors printed onto the cells and exhibit greater heat resistance.

\section{H. 6082 Aluminium Alloy as Thermal system}

6082 an alloy in the wrought AL-magnesium-silicon family (6000 series). It is typically formed by rolling and extrusion, but as a alloy it was not used in casting. It forged and clad, but that is not general practice with this alloy. It cannot be work hardened, but is commonly heat treated to produce tempers with a higher strength but lower ductility .The alloy composition of 6082 aluminium is:

Table -3.0 Alloy 6082 composition

\begin{tabular}{|c|c|}
\hline Aluminium & 95.2 to $98.3 \%$ \\
\hline Chromium & $0.25 \% \max$ \\
\hline Copper & $0.1 \% \max$ \\
\hline Iron & $0.5 \% \max$ \\
\hline Magnesium and manganese & 0.6 to $1.2 \%$ \\
\hline Silicon & 0.7 to $1.3 \%$ \\
\hline Titanium & $0.1 \% \max$ \\
\hline Zinc & $0.2 \% \max$ \\
\hline Residuals & $0.15 \% \max$ \\
\hline
\end{tabular}

\section{Properties}

Typical material properties for 6082 aluminum alloy include

Published By:

Blue Eyes Intelligence Engineering 


\section{Density}

Young's modulus

: $2.71 \mathrm{~g} / \mathrm{cm}^{3}$, or $169 \mathrm{lb} / \mathrm{ft}^{3}$.

: $71 \mathrm{GPa}$, or 10 Msi.

Ultimate tensile strength: 135 to $325 \mathrm{MPa}$, or 19 to $47 \mathrm{ksi}$.

Yield strength

: $281 \mathrm{MPa}$, or 12 to $40 \mathrm{ksi}$.

Thermal Expansion

$23.1 \mu \mathrm{m} / \mathrm{m}-\mathrm{K}$.

Solidus

: $575^{\circ} \mathrm{C}$ or $1070^{\circ} \mathrm{F}$

\section{Design of Fin system}

As the aim of fins is to transfer more heat in minimal amount of time, we designed two different layouts for the fins to transfer the heat in one we used parallel arrangement of fins whereas in the second layout we used checked design but keeping the volume of PCM material the same. Due to low thermal conductivity of PCM material we need to have maximum area of contact for maximum heat transfer and to lower the temperature of the solar panel as soon as possible but by simply adding more aluminium decreases the heat storage so in this aspect we used different designs where we kept the volume of pcm material constant hence to get optimal results, without decreasing PCM material. As aluminium has high thermal conductivity it can easily spread heat throughout the PCM material with the right design we can spread heat evenly that is where checked design comes in which can spread heat more evenly than parallel design. There is a need for insulation of the box containing PCM as we do not need extra heat through needlessly exposed areas like which can reduce the heat storage of PCM material from fins hence we need to insulate the structure except the solar panel.

\section{THE EXPERIMENTAL SET UP}

For the construction of the finned PV-PCM system we are fabricating the box which will contain the PCM material and the fins which transfer heat from solar panel to PCM material with aluminum because of its good thermal conductivity and the fins which transfer heat from solar panel to PCM material. Thermocouples were installed on different fins to get more accurate data along with sensors (photo diode for irradiance measurement and thermocouples for temperature readings at different locations) to an Arduino board which converts the analog output from sensors to digital output to recor the and store the data in computer in different intervals. The PCM material is melt and added to the box and the fins are used to enclose the box. Then the solar panel is placed on the other end of fins a thermocouple is placed on the top surface of the solar panel which is also integrated to the Arduino board and the entire enclosure is clamped together. The constructed finned PV-PCM system is placed in the sunlight

The solar irradiance incident on the Photovoltaic is distributed uniformly across the surface as the top surface is considered as perfectly clean to avoid the effect of dirt and clear sky conditions are considered to avoid the nonuniformity caused due to clouds. Since the individual layers of PV are very thin, they are considered to be homogeneous and isotropic. The selected phase Change Material is placed into the Aluminium finned system .

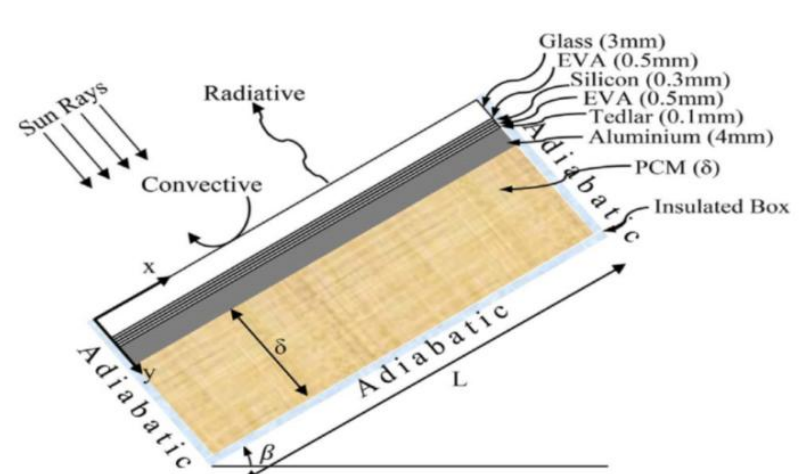

Fig-4 Schematic model of Finned Aluminium PV-PCM system

Solar Panel is attached to the finned PV-PCM system and its thermally insulated on the boundaries of finned system and Thermal and Irradiance sensors are placed in the finned PV-PCM system to find experimental data. The presence of fins can reduce the adverse effect of crystalline segregation of phase change material. Thus, the PCM in solid and liquid phases is assumed as homogeneous and isotropic. Since the operating temperature range is not too wide, the thermal properties of the PV and phase change material (in same phase) are considered to be unaffected with change in temperature. It was considered the bottom and side walls of box were thermally insulated and neglected the het losses. Due to the symmetry of the system along the $\mathrm{Z}$ direction and the side walls of the system are thermally insulated, twodimensional and the data from the sensors is collected with respect to time and the simulated analysis.

\section{a) Modelled design of Fin system DESIGN I}


Fig 4.0. ANSYS Model with fin system 1 And Fabricated model of Fin system 2 


\section{PVT Cell Performance Characteristics and Efficiency with Phase Change Material}

\section{DESIGN II}

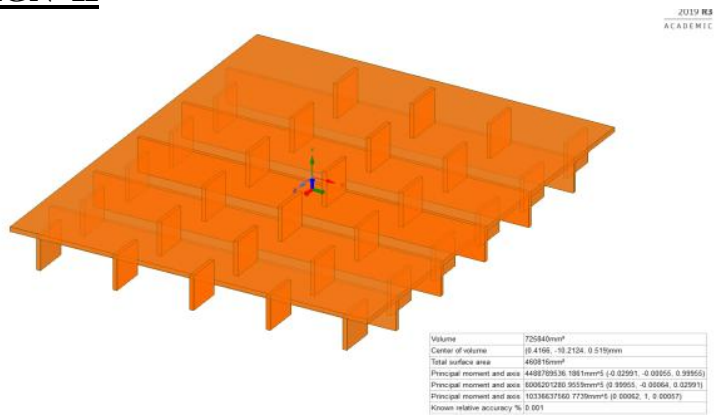

Fig 4.2 .ANSYS Model with fin system 2

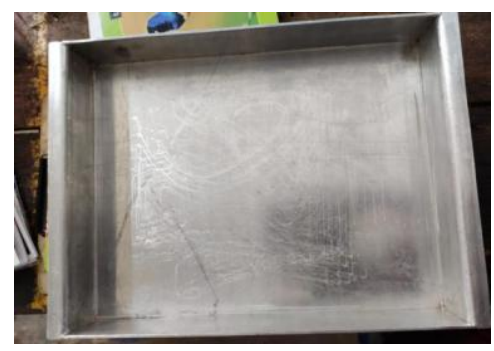

Fig 4.3. Fabricated model of Aluminium Box

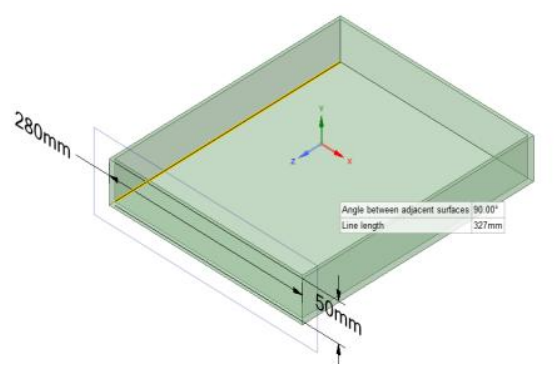

Fig4.4 ANSYS Model of Aluminium box

\section{A. Theoretical Calculations :}

Conductive heat transfer

$$
\frac{Q}{t}=\frac{K \cdot A \cdot \Delta T}{L}
$$

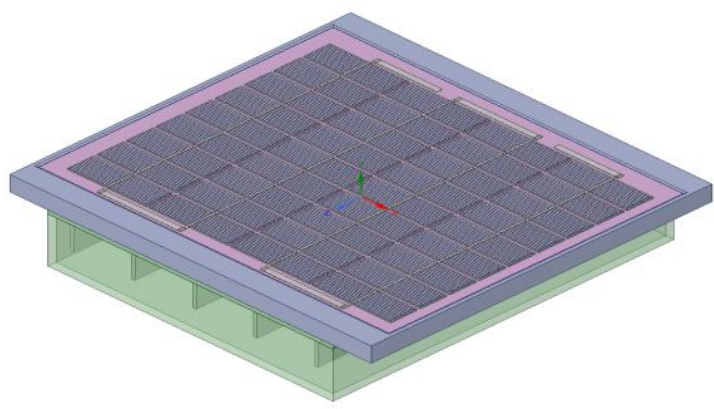

Fig 4.5 Aluminium Finned PV-PCM System 1

Known dataSurface area of the solar pane $\quad=93800 \mathrm{~mm}^{2}$.

Total surface area of the plate in contact with solar panel $=93800 \mathrm{~mm}^{2}$

Thermal conductivity of solar panel $=1.084 \mathrm{~W} / \mathrm{mk}$
Thermal conductivity of PCM

Mass of PCM in box

Latent heat of PCM

$=2.74 \mathrm{~W} / \mathrm{mk}$

$=7.19 \mathrm{Kg}$

$=153.7 \mathrm{~J} / \mathrm{g}$

Heat holding capacity of $7.19 \mathrm{~kg}$ of PCM $=1105 \mathrm{KJ}$

Assumed value of Irradiance $\quad=1380 \mathrm{~W} / \mathrm{m}^{2}$

Heat transfer rate $(\mathrm{Q} / \mathrm{t})=$ Irradiance $\times$ Sur,Area of the panel $\mathrm{Q} / \mathrm{t}=1380 \times\left(335 \times 280 \times 10^{-6}\right)=129.44 \mathrm{~W}$

Time before all the PCM melts $(\mathrm{T})=$ Latent heat/heat transfer $=8532$ Sec ( 2 hrs 22mins)

Assuming the temperature of $\mathrm{PCM} 29^{\circ} \mathrm{C}$

\section{CASE 1}

Total surface area of the fin design 1 in contact with the $\mathrm{PCM}=195500 \mathrm{~mm}^{2}$

Temperature of aluminium keeping $\mathrm{Q} / \mathrm{t}=129.5 \mathrm{~W}$

129.5=K.A.(Ta-Tp)/L

$129.5=211 \times .1955 \times(\mathrm{Ta}-29) / 0.004=\mathrm{Ta}=29.012{ }^{\circ} \mathrm{C}$

Temperature of solar panel $\mathrm{Tp}=((\mathrm{Q} / \mathrm{t}) . \mathrm{L} /(\mathrm{K} . \mathrm{A}))+\mathrm{Ta}$

$\mathrm{T}=((129.5 \times .0039) \div(1.084 \times .93800))+29.012=33.97{ }^{\circ} \mathrm{C}$

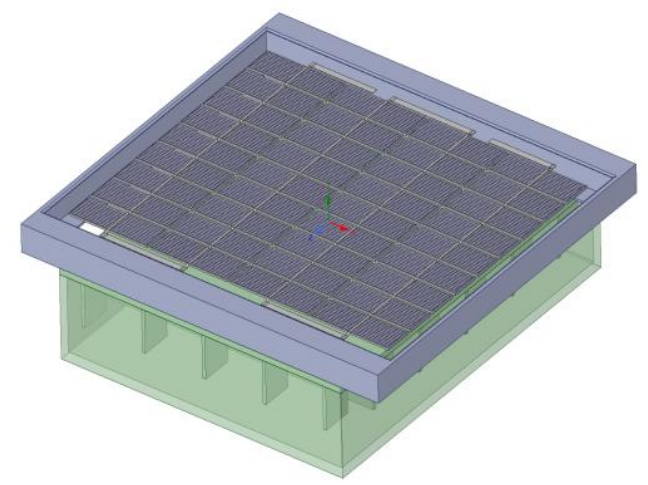

Fig 4.6 Aluminium Finned PV-PCM SYTEM 2

\section{CASE 2}

Area of fin design 2 in contact with PCM $=236240 \mathrm{~mm}^{2}$

Temperature of aluminiumTa ,keeping Q/t=129.5 W

129.5=K.A.(Ta-Tp)/L

$129.5=211 \times .23624 \times($ Ta-29) $/ 0.004$

$\mathrm{Ta}=29.0103^{0} \mathrm{C}$

Temperature of solar panel Tp= ((Q/t). L / (K.A)) $+\mathrm{Ta}$

$\mathrm{Tp}=((129.5 \times .0039) \div(1.084 \times .93800))+29.0103=32.963^{0} \mathrm{C}$

\section{CASE 3}

Area of $\mathrm{Al}$ plate in contact with PCM in absence of fins $=93800 \mathrm{~mm}^{2}$

Temperature of aluminium keeping $\mathrm{Q} / \mathrm{t}=129.5 \mathrm{~W}$

129.5=K.A.(Ta-Tp)/L

$129.5=211 \times .0938 \times(\mathrm{Ta}-29) / 0.004=\mathrm{Ta}=29.026^{0} \mathrm{C}$

Temperature of solar panel Tp= ((Q/t). L / (K.A)) $+\mathrm{Ta}$

$\mathrm{Tp}=((129.5 \times .0039) \div(1.084 \times .93800))+29.026=35.993^{0} \mathrm{C}$

\section{B. Analytical Study (Simulation)}

The Fin systems of different designs were modeled in Ansys Spaceclaim and the analysis of different Fin Systems were done Autodesk Fusion 360. Analysis consists of two systems, where Rubber is used as insulation material to not allow the heat to flow out of the system. While conducting the simulations heat input was given to top surface of aluminium fin system, steady state conditions were assumed.

\section{Published By:}

Blue Eyes Intelligence Engineering

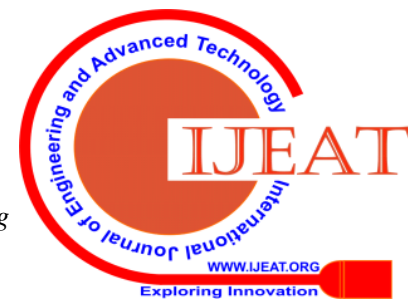




\section{Thermal Loads Applied:}

(i)Uniform heat flux on top surface of fin Irradiance from Sun $=1380 \mathrm{~W} / \mathrm{m} 2$

(ii)Temperature of Phase Change Material and Rubber insulation $=29^{0} \mathrm{C}$

(iii)Time taken for melting of PCM = 2 h 22 mins

(iv)Top surface area of the Al Fin material $=0.0938 \mathrm{~m} 2$

(v)Heat transfer rate from Solar Panel to Aluminium top surface $=129.44 \mathrm{~W}$

Table-4.1 Material properties for Analysis

\begin{tabular}{|l|l|c|c|c|}
\hline $\begin{array}{l}\text { S. } \\
\text { no }\end{array}$ & $\begin{array}{l}\text { Material } \\
\text { Properties }\end{array}$ & PCM & $\begin{array}{l}\text { Alum } \\
\text { inium }\end{array}$ & $\begin{array}{l}\text { Rub } \\
\text { ber }\end{array}$ \\
\hline 1 & $\begin{array}{l}\text { Density (kg/ } \\
\mathrm{m}^{3} \text { ) }\end{array}$ & 3360 & 2710 & 930 \\
\hline 2 & $\begin{array}{l}\text { Young's } \\
\text { Modulus (MPa) }\end{array}$ & 0 & 68900 & 3 \\
\hline 3 & $\begin{array}{l}\text { Thermal } \\
\text { Conductivity (W } \\
\text { /m.K) }\end{array}$ & 2.74 & 211 & 14 \\
\hline 4 & $\begin{array}{l}\text { Specific } \\
\text { Heat(J/Kg.K) }\end{array}$ & 2300 & 897 & 1800 \\
\hline
\end{tabular}

\section{Aluminium Finned PV-PCM System 1} CASE -1

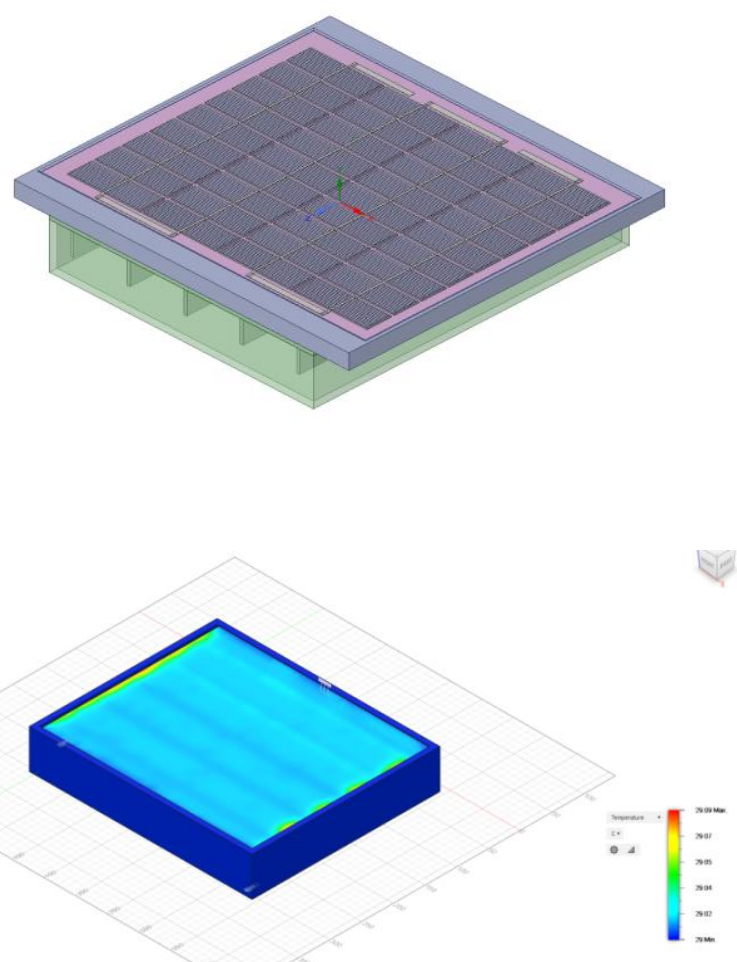

Fig 4.7 . Temperature in Finned system 1

The final temperature of thermal analysis was $29.09^{\circ} \mathrm{C}$ which is melting point of HS 27 Phase Change Material for given thermal loads obtained in mathematical calculations.

\section{Aluminium Finned Pv-Pcm System 2}

\section{CASE 2}
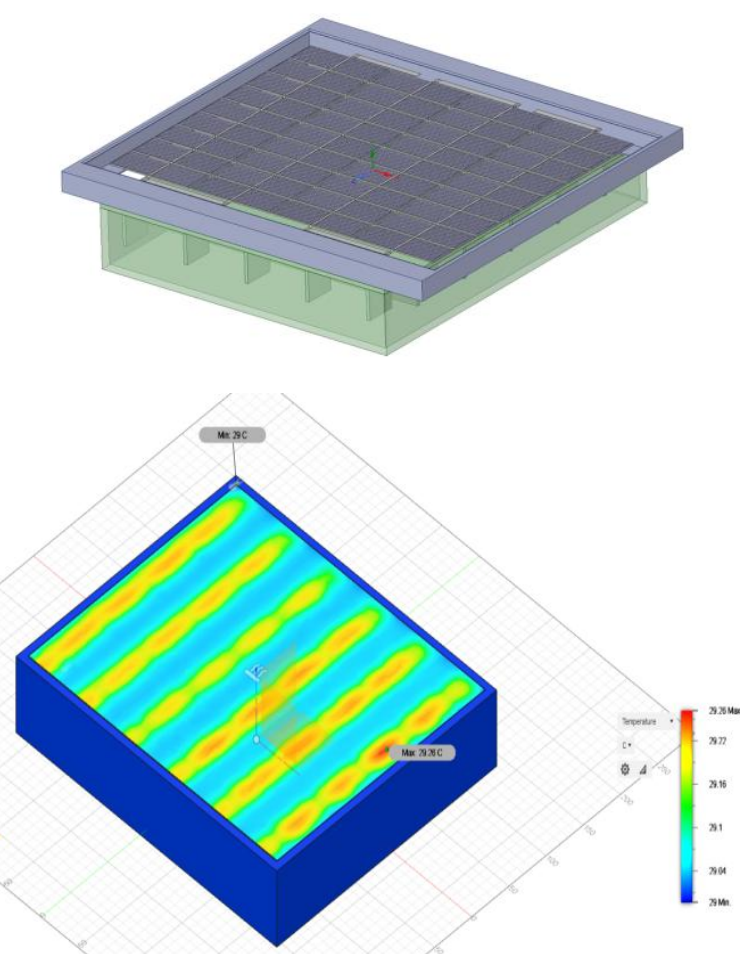

Fig 4.8. Temperature in Finned system 2

This thermal analysis show that final temperature of the surface is 29.26. which is melting point of HS 29 Phase Change Material for given thermal loads obtained in mathematical calculations.

E)Aluminium Box Without Finned Pv-PCM System 3

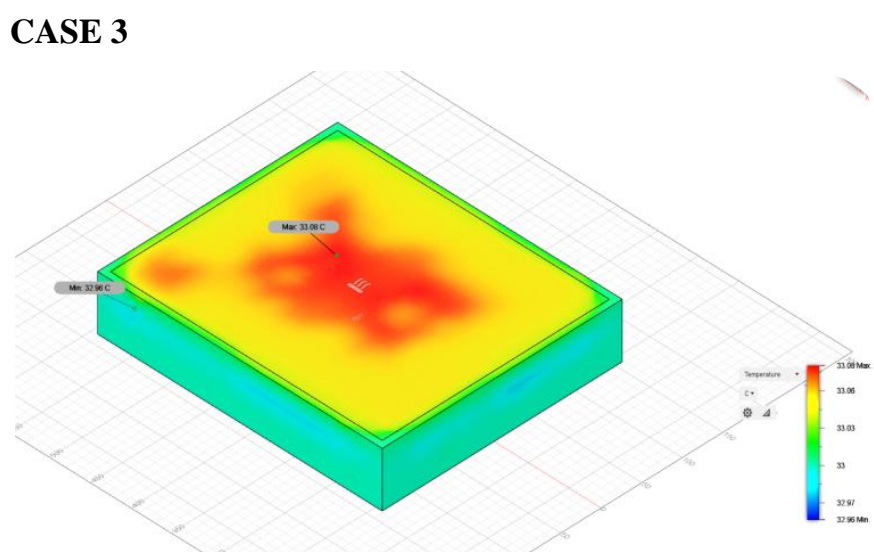

Fig 4.9 Temperature in system 3 without fins

\section{RESULTS AND DISCUSSION}

The most important parameter in manufacturing and building a PVT panel is its efficiency. The PV panel temperature increment will lowers the electrical output. The efficiency of a photo voltaic cell is decreased by 0.4 to $0.5 \%$ for every $1^{\circ} \mathrm{C}$ rise in temperature. Mathematical and thermal analysis of PVT-PCM with fin and with out fin system was carried and final temperature was computed .




Table -5.0 Theoretical values and analysis values

\begin{tabular}{|c|c|c|c|c|}
\hline $\begin{array}{c}\text { S.n } \\
\mathbf{0}\end{array}$ & Material & Model & $\begin{array}{c}\text { Theoretic } \\
\text { al value } \\
\mathbf{( T}_{\mathbf{t}} \mathbf{)}\end{array}$ & $\begin{array}{c}\text { Analytical } \\
\text { value } \\
\mathbf{( T}_{\mathbf{a}} \mathbf{)}\end{array}$ \\
\hline 1 & HS- 27 & Model -A & $33.97{ }^{0} \mathrm{C}$ & $29.09{ }^{0} \mathrm{C}$ \\
\hline 2 & HS-27 & Model -B & $32.96{ }^{0} \mathrm{C}$ & $29.26{ }^{0} \mathrm{C}$ \\
\hline
\end{tabular}

The Solar panel temperature was found $58^{0} \mathrm{C}$ in the absence of PCM and Finned system and the Derating of solar panel was found $13.2 \%((58-25) \times .4=13.2 \%)$ by taking the temperature coefficient of the solar panel $0.4 \%$.

Table -5.1 Models and its Derating Factor

\begin{tabular}{|c|l|c|}
\hline $\begin{array}{c}\text { S.n } \\
\text { o }\end{array}$ & \multicolumn{1}{|c|}{ CASE } & $\begin{array}{c}\text { Derating of Solar } \\
\text { Panel }\end{array}$ \\
\hline 1 & In absence of PCM material & 13.2 \\
\hline 2 & Fin Design-I Model -A & 3.588 \\
\hline 3 & Fin Design-II Model -B & 3.18 \\
\hline 4 & With PCM without fins & 4.39 \\
\hline
\end{tabular}

From the values it was clear that less derating factor (loss) closer is the performance of solar panel at standard conditions. Deign of Fin system - II gives the lesser derating factor in compared with system 2. It was also found derating factor is 13.2 (amount to loss in efficiency of 13.2\%) in the absence of Phase change material. Different fin layouts and size can further reduced the derating of solar panel. PVTPCM systems maintenance was very low and high panel sustainability while comparing with other cooling methods. It was clear that increment of thermal conductive area using the Fin system with Phase change material will gives the better results. We can increase the solar panel cooling by better selection of geometry of fins along with Phase change material of high thermal conductivity. The Developed model of PVT-

PCM system can be escalated its electrical efficiency by encapsulating the nano particles in to the PCM.

\section{CONCLUSIONS}

A new PV/T panel design was developed to optimize the generation of electricity and heat. In this present work, the experiment analysis was conducted with different fin design with PCM, with out PCM material and efficiency enhancement of PV integrated model was developed. The experimental models were compared with theoretical models and derating factor was determined . The derating factor decrement can enhance the solar panel electrical output along with thermal storage. Using different Fin design, layout and PCM material, we are able to reduce the temperature of solar panel. From the studies it is believed that the optimizing of solar panel cooling can be found for real applications. It was also found that the proper selection of PCM material with desirable properties can enhance the thermal conductivity . Integrating the PCM on back side of the solar panel module results and decrease the temperature of panel modules propagates the increase in electrical power and thermal efficiency. The PVT-PCM system efficiency can be easily increased by increasing the PCM volume to store more heat with out increasing the panel temperature during the day time. Researcher studies shown the PVTPCM system with nano materials inclusion in the PCM can drop the temperature further and increase its efficiency by 6 to $12 \%$.

\section{REFERENCES}

1. Browne MC, Lawlor K, Kelly A, Norton B, McCormack SJ. Indoor characterisation of a photovoltaic/thermal phase change material system. Energy Procedia2015;70:163e71.

2. Du et al.Du, B.; Hu, E.; Kolhe, M. Performance analysis of water cooled concentrated photovoltaic (CPV) system. Renew. Sustain. Energy Rev. 2012, 16, 6732-6736. [CrossRef]

3. K. Vats, V. Tomar, G.N. Tiwari, Effect of packing factor on the performance of a building integrated semi-transparent photovoltaic thermal (BIPVT) system with air duct, Energy Buildings 53 (2012) 159-165.
Published By:

Blue Eyes Intelligence Engineering \& Sciences Publication (C) Copyright: All rights reserved. 